\title{
Factors Affecting Conjugal Transfer of Plasmids Encoding Mercury Resistance from Pure Cultures and Mixed Natural Suspensions of Epilithic Bacteria
}

\author{
By PAUL A. ROCHELLE, $\dagger$ JOHN C. FRY* AND MARTIN J. DAY \\ Department of Applied Biology, University of Wales Institute of Science and Technology, \\ PO Box 13, Cardiff CF1 3XF, UK
}

(Received 30 March 1988; revised 6 August 1988; accepted 24 October 1988)

\begin{abstract}
Sixty-five pure cultures of epilithic bacteria were examined for their ability to transfer mercury resistance to Pseudomonas aeruginosa; five isolates transferred plasmids encoding mercury resistance with frequencies ranging from $8.4 \times 10^{-8}$ to $2.8 \times 10^{-3}$ per recipient. Two of the plasmids, pQM3 and pQM4, encoded narrow-spectrum mercury resistance, pQM3 also encoded streptomycin resistance, and both plasmids were broad host range. Maximum transfer frequencies of epilithic plasmids from pure cultures occurred over the range $10-25^{\circ} \mathrm{C}$ at $3.5 \mathrm{~g} \mathrm{C}$ $1^{-1}$ and with donor to recipient ratios of $0 \cdot 4-30$. Transfer occurred over a range of $\mathrm{pH}$ values $(\mathrm{pH}$ $5 \cdot 0-8.0)$ but the effect of $\mathrm{pH}$ was most significant at non-optimal temperature. Anaerobiosis inhibited transfer of one epilithic plasmid, $\mathrm{pQM1}$, but not that of $\mathrm{pQM3}$. Plasmids encoding mercury resistance were also transferred frc $n$ mixed natural suspensions of epilithic bacteria (MNS) to Pseudomonas spp. on agar in the laboratory. Transfer from MNS occurred over a wide range of environmentally relevant conditions with maximum frequencies $\left(2 \times 10^{-5}\right.$ per recipient) after $24 \mathrm{~h}$, at $25^{\circ} \mathrm{C}$, pH 5.5-8.0 and on a medium containing $10 \mathrm{~g} \mathrm{C}^{-1}$. The optimal initial cell density of MNS and recipient was $1.7 \times 10^{5} \mathrm{c.f.u} . \mathrm{cm}^{-2}$ and highest frequencies were obtained with donor to recipient ratios ranging from $1.2 \times 10^{-1}$ to $1.7 \times 10^{-3}$. Most of the plasmids (54\%) from MNS transferred from their original $P$. aeruginosa transconjugants to a Pseudomonas putida strain, with frequencies ranging from $1.1 \times 10^{-6}$ to greater than $1.0 \times 10^{-1}$ per recipient. The majority $(80 \%)$ of the plasmids were larger than $300 \mathrm{~kb}$ and all of these large plasmids encoded UV resistance in addition to mercury resistance. Twenty-one plasmids $>300 \mathrm{~kb}$ were analysed by restriction digests and were shown to be similar, with only minor structural alterations. One of these alterations was associated with the acquisition of streptomycin resistance. Overall, these results suggest that the epilithic bacteria examined possess the potential to transfer mercury resistance within the epilithon under a wide range of environmentally relevant conditions.
\end{abstract}

\section{INTRODUCTION}

Plasmids have been detected in bacteria isolated from a variety of aquatic environments. Frequencies of plasmid incidence in marine isolates range from $23 \%$ to $46 \%$ (Glassman \& McNicol, 1981; Hada \& Sizemore, 1981; Simon et al., 1982; Kobori et al., 1984). A survey of plasmids in freshwater epilithic bacteria (Burton et al., 1982) showed that $10-15 \%$ of isolates contained at least one plasmid, depending on whether the samples were from unpolluted or polluted sites.

Bacteria isolated from water have been shown to transfer plasmids in pure-culture matings (Shaw \& Cabelli, 1980; Toranzo et al., 1984; Gauthier et al., 1985) and a number of reports have

† Present address: Program in Social Ecology, University of California, Irvine, CA 92717, USA.

Abbreviation: MNS, mixed natural suspensions of epilithic bacteria. 
investigated the influence of various factors on conjugal plasmid transfer. The effects of temperature and pH have been studied (Shenderov, 1971; Singleton \& Anson, 1981, 1983; Altherr \& Kasweck, 1982; Kelly \& Reanney, 1984; Gauthier et al., 1985) but few reports have dealt with the effects of mating time, nutrient status, or donor to recipient ratio (Beringer, 1974; Gauthier et al., 1985), and reports on the effect of anaerobiosis on conjugation have been conflicting (Anderson, 1975; Burman, 1975; Graves \& Riggs, 1980). Most of these studies used pure cultures of bacteria: genetic work with mixed natural communities is rare (Bale et al., 1988).

The epilithon of freshwater rivers contains a dense population of closely spaced, fixed bacteria (Lock et al., 1984), which makes it an ideal community for studying plasmid transfer in aquatic environments. The aim of this work was to isolate epilithic bacteria containing conjugative plasmids and to determine the optimal conditions for transfer of these plasmids to Pseudomonas strains, which are commonly-occurring aquatic bacteria (Nuttall, 1982; Jones et al., 1986). We also undertook to determine the optimal conditions for the transfer of plasmids from mixed natural suspensions of epilithic bacteria (MNS), with the aim of understanding the environmental factors most likely to determine the rates of plasmid transfer in natural aquatic habitats. The transferred plasmids were then characterized further to discover whether one particular type was transferred most often. Work in this laboratory has already demonstrated the presence of a conjugative plasmid encoding mercury resistance in the epilithon (Bale et al., 1987,1988 ), so the mercury-resistance phenotype was also used in this study.

\section{METHODS}

Bacterial strains and growth conditions. The bacterial strains used in this study are shown in Table 1. All strains were routinely maintained on standard plate count agar (PCA; Oxoid CM463) containing appropriate selective agents and incubated at $30^{\circ} \mathrm{C}$. Rifampicin-resistant mutants of these strains were used as recipients in mating experiments. Liquid cultures were grown in $10 \mathrm{ml}$ nutrient broth (NB; Oxoid CM3) for $18 \mathrm{~h}$ in an orbital incubator at $30^{\circ} \mathrm{C}$, except for epilithic isolates, which were incubated at $20^{\circ} \mathrm{C}$.

Isolation of epilithic strains and preparation of epilithic suspensions. Stones were collected from a shallow area in the lower reaches of the organically polluted River Taff, South Wales (Mawle et al., 1985). Epilithic suspensions were prepared by scrubbing the stones with a sterile toothbrush in $100 \mathrm{ml}$ sterile distilled water followed by stomaching (Burton et al., 1982). This procedure gave the MNS used subsequently. Viable counts were performed on PCA incubated at $20^{\circ} \mathrm{C}$ for $4 \mathrm{~d}$. Mercury-resistant strains were isolated by plating serial dilutions of epilithic suspension onto $\mathrm{PCA}+\mathrm{HgCl}_{2}(27 \mu \mathrm{g} \mathrm{ml}-1)$, and pseudomonad-like mercury-resistant strains by plating onto a pseudomonad selective medium (PSM), made from pseudomonas agar base (Oxoid CM559) with a cetrimide/nalidixic acid supplement (Oxoid SR 102) $+\mathrm{HgCl}_{2}\left(27 \mu \mathrm{g} \mathrm{ml}^{-1}\right.$ ). Plates were incubated at $20^{\circ} \mathrm{C}$ for $4 \mathrm{~d}$. Epilithic isolates were identified using API20B kits (API Laboratory Products) designed for aerobic, heterotrophic bacteria, and a probabilistic identification matrix for Gram-negative, aerobic, non-fermentative bacteria (Holmes et al., 1986).

Plasmid detection. Plasmids were detected using the method of Kado \& Liu (1981) with the modifications of Rochelle et al. (1986). Plasmid sizes were determined using the size standards and multiple regression method described by Rochelle et al. (1986). In our laboratory this method gave average $95 \%$ confidence invervals of $\pm 4.4 \%$ of the mean plasmid size.

Detection of transferable mercury resistance in epilithic isolates and other pure cultures. Mercury-resistant and pseudomonad-like mercury-resistant isolates were screened for the presence of plasmids. Sixty-five of these isolates containing plasmids $\geqslant 30 \mathrm{~kb}$ were used as donors in mating experiments with a variety of $P$. aeruginosa strains (PAO2002, PU21, PAO348) as recipients. Equal volumes (1 ml) of donor and recipient NB cultures were mixed and filtered through $0.22 \mu \mathrm{m}$ cellulose acetate membrane filters ( $25 \mathrm{~mm}$ diam.; Oxoid N25/22UP). The filters were incubated face up on the surface of PCA plates for $24 \mathrm{~h}$ at $20^{\circ} \mathrm{C}$, then the cells on the filter were resuspended by vortex mixing in $10 \mathrm{ml}$ of $1 / 10$-strength $\mathrm{NB}$ and serial dilutions were plated onto selective media. Recipient counts were performed on PCA + rifampicin $\left(100 \mu \mathrm{g} \mathrm{ml}^{-1}\right)$ and transconjugant counts on PCA + rifampicin $\left(100 \mu \mathrm{g} \mathrm{ml}^{-1}\right)+\mathrm{HgCl}_{2}\left(27 \mu \mathrm{g} \mathrm{ml}^{-1}\right)$. Selective plates were incubated at $20^{\circ} \mathrm{C}$ for $4 \mathrm{~d}$. The presence of plasmids in the transconjugants was confirmed by gel electrophoresis of DNA samples.

Detection of plasmid transfer from epilithic suspensions. The MNS $(1 \mathrm{ml})$ was mixed with $1 \mathrm{ml}$ of a broth culture of recipient bacteria and poured onto the surface of a very dry PCA plate. The liquid rapidly soaked into the agar. The incubation conditions generally used for these mating plates were $20-25^{\circ} \mathrm{C}, 24 \mathrm{~h}, \mathrm{pH} 7 \cdot 0$, on $\mathrm{PCA}$ plates $\left(3.2 \mathrm{~g} \mathrm{Cl}^{-1}\right)$. After incubation, the growth on the plates was harvested, resuspended in $10 \mathrm{ml} 1 / 10$-strength NB and then plated onto selective media. PSM + rifampicin $\left(100 \mu \mathrm{g} \mathrm{ml} \mathrm{m}^{-1}\right)$ was used for recipient counts and 
Table 1. Bacterial strains used in this study

Species

Pseudomonas

aeruginosa

$\begin{array}{ll} & \text { PU21 } \\ & \text { PAO348 } \\ & \text { PP3 } \\ \text { P. putida } & \text { KT2440 } \\ & \text { PAR153 } \\ & \text { 10038 } \\ \text { P. fluorescens } & \text { AR41 } \\ & \text { AR17 } \\ \text { P. cepacia } & \text { PAR161 } \\ & \text { PAR167 } \\ \text { P. maltophilia } & \text { 10499 } \\ & \text { AR27 } \\ \text { Alteromonas } \text { sp. } & \text { PAR174 } \\ \text { A. putrefaciens } & \text { 10695 } \\ \text { Escherichia coli } & \text { J53 }\end{array}$

LE392

Klebsiella

pneumoniae

Proteus vulgaris

Acinetobacter

calcoaceticus

Unidentified

Gram-negative rod

Strain

PAR166
Genotype/phenotype*

argH32 str-39 chl-2 rec-1

ilvB112 leu-1 str-1 Rif ${ }^{r}$

met-28 trp-6 lys-12 pro-82 his-114 ilv-226

leu-13 hsdS20; FP-

Prototrophic

hsdRI hsdM ${ }^{+}$; prototrophic

$\mathrm{Hg}^{r}$; prototrophic; $\mathbf{P}^{+}$

Prototrophic

Prototrophic; $\mathbf{P}^{-}$

$\mathrm{Hg}^{\mathrm{r}}$; prototrophic; $\mathbf{P}^{-}$

$\mathrm{Hg}^{\mathrm{r}} \mathrm{Sm}^{\mathrm{r}}$; prototrophic; $\mathrm{P}^{+}$

$\mathrm{Hg}^{\mathrm{r}} \mathrm{Sm}^{\mathrm{r}}$; prototrophic; $\mathrm{P}^{+}$

Met $^{-}$

$\mathrm{Met}^{-} \mathbf{P}^{-}$

$\mathrm{Hg}^{\mathrm{r}}$; prototrophic; $\mathrm{P}^{+}$

Prototrophic

proB22 metF63

supE44 supF58 lacY1 galK2 galT22

metB1 trpR55 hsdR514; $\lambda^{-} \mathrm{F}^{-}$

$8172 \quad$ Prototrophic

6213 Prototrophic

BD413 Prototrophic
Reference/source $\uparrow$

Chandler \& Krishnapillai (1974)

Jacoby (1974)

V. Krishnapillai (pers. comm.)

Senior et al. (1976)

Bagdasarian et al. (1981)

Epilithic isolate

NCTC 10038

Epilithic isolate

Epilithic isolate

Epilithic isolate

Epilithic isolate

NCTC 10499

Epilithic isolate

Epilithic isolate

ATCC 10695

Bachmann (1987)

Maniatis et al. (1982)

NCTC 8172

NCIB 6213

NCIB 11826

Epilithic isolate

* $\mathrm{P}^{+}$, contains at least one plasmid; $\mathbf{P}^{-}$, plasmid free.

$\uparrow$ NCTC, National Type Culture Collection; NCIB, National Collection of Industrial Bacteria; ATCC, American Type Culture Collection.

PSM + rifampicin $+\mathrm{HgCl}_{2}\left(27 \mu \mathrm{g} \mathrm{ml}^{-1}\right)$ for transconjugant counts. Selective plates were incubated at $30^{\circ} \mathrm{C}$ for $48 \mathrm{~h}$. Transfer of other resistance markers was also tested using the following selective agents in place of $\mathrm{HgCl}_{2}$ : potassium tellurite $\left(127 \mu \mathrm{g} \mathrm{ml}^{-1}\right)$, streptomycin $\left(300 \mu \mathrm{g} \mathrm{ml}^{-1}\right)$, kanamycin $\left(400 \mu \mathrm{g} \mathrm{ml}^{-1}\right)$, and gentamicin $(150 \mu \mathrm{g}$ $\mathrm{ml}^{-1}$ ). Liquid matings were performed by adding $1 \mathrm{ml}$ MNS to $1 \mathrm{ml}$ of a broth culture of recipient bacteria and incubating at $20^{\circ} \mathrm{C}$ for $24 \mathrm{~h}$ before plating onto selective media. Transfer frequencies were expressed in all mating experiments as the mean number of transconjugants per recipient.

Confirmation and characterization of transconjugants. The identities of $P$. aeruginosa PAO348 transconjugants from MNS matings were confirmed by replica plating onto minimal salts agar (Bale et al., 1987) + glucose (1 g $\left.\mathrm{l}^{-1}\right)$ supplemented with different combinations of the following amino acids $\left(100 \mu \mathrm{g} \mathrm{ml}^{-1}\right)$ : methionine, tryptophan, lysine, histidine, proline, valine, leucine. Resistance markers other than mercury were determined by replica plating onto PCA containing individual antimicrobial agents $\left(100 \mu \mathrm{g} \mathrm{ml}^{-1}\right)$ : streptomycin, gentamicin, tetracycline, carbenicillin $\left(1 \mathrm{mg} \mathrm{ml}^{-1}\right)$, potassium tellurite $\left(127 \mu \mathrm{g} \mathrm{ml}^{-1}\right)$. P. aeruginosa PAO348 transconjugants were used as donors in pure-culture matings with P. putida KT2440 to determine the ability of the plasmids from MNS to re-transfer. To test for UV resistance, dilution series of plasmid-containing and plasmid-free strains were irradiated on the surface of a UV transilluminator $(1.3 \mathrm{~mW} \mathrm{~cm}-2$ at $302 \mathrm{~nm})$. After irradiation, all plates were incubated in the dark and resistance was determined by comparing the percentage survival of the strains.

Factors affecting conjugation. The standard incubation conditions for pure-culture matings were $20^{\circ} \mathrm{C}, 24 \mathrm{~h}$, $\mathrm{pH} \mathrm{7.0,} \mathrm{on} \mathrm{PCA} \mathrm{plates}\left(3.5 \mathrm{~g} \mathrm{Cl}^{-1}\right)$. The amount of organic nutrients in PCA was calculated as $\mathrm{g} \mathrm{Cl}^{-1}$ based on the percentage carbon in the individual nutrients of PCA. Different nutrient status regimes were attained by using plates containing varying amounts of PCA. Thus, $0 \mathrm{~g} \mathrm{Cl}^{-1}$ was Bacto-agar (Difco 0140-01) with no added carbon in the form of PCA. The values do not take into account any available carbon that may have been present in the agar. The effects of temperature, $\mathrm{pH}$, mating time, nutrient status, donor to recipient ratio, and anaerobiosis on plasmid transfer from epilithic isolates to $P$. aeruginosa were investigated. The basic mating protocol was as described above except that selective plates in experiments with pure cultures were incubated at $30^{\circ} \mathrm{C}$ for $48 \mathrm{~h}$. An epilithic plasmid encoding mercury resistance (pQM1, $254 \mathrm{~kb}$; Bale et al., 1987) and the antibiotic-resistance plasmid RP1 (Lowbury et al., 1969) were also studied in the pure-culture experiments. P. aeruginosa PAO2002 was 
used as the donor for pQM1 and RP1 and $P$. aeruginosa PU21 was the recipient. For broth matings, $1 \mathrm{ml}$ volumes of NB cultures of donor and recipient bacteria were mixed and incubated without filtering.

Anaerobic matings. The basic mating protocol was performed in a strict anaerobic environment (glove box isolator, $100 \% \mathrm{~N}_{2}$ ) with filters containing donors and recipients incubated on PCA plates containing $0.5 \% \mathrm{KNO}_{3}$ as the terminal electron acceptor (Van Hartingsveldt $e t$ al., 1971); all media that were incubated anaerobically contained $0.5 \% \mathrm{KNO}_{3}$. Selective plates were placed in anaerobic jars (BBL Microbiology Systems), set up inside the anaerobic cabinet, and then transferred to a $20^{\circ} \mathrm{C}$ (pQM1, pQM3) or $30^{\circ} \mathrm{C}$ (RP1) incubator.

Phenotypic tests for conjugative plasmids. Transferred mercury-resistance plasmids were tested for additional phenotypes using Mastring-S antibiotic discs (M26 and M47; Mast Laboratories) on DST agar (Oxoid CM261) incubated at $20^{\circ} \mathrm{C}$ for $48 \mathrm{~h}$. Organomercurials were used at the following concentrations in PCA $\left(\mu \mathrm{g} \mathrm{ml} \mathrm{m}^{-1}\right)$ : fluorescein mercuric acetate (85.0), merbromin (375), phenylmercuric acetate (168), and thimerosal (40.5). The media were inoculated with broth cultures of the epilithic donor, the mercury-resistant transconjugant and the plasmid-free recipient.

Endonuclease digestion. Bacteria from which plasmids were to be isolated for restriction digests were grown in $50 \mathrm{ml} \mathrm{NB}$ for $16 \mathrm{~h}$ at $30^{\circ} \mathrm{C}$ in an orbital incubator. Plasmids were isolated from cell lysates by sucrose gradient centrifugation (Wheatcroft \& Williams, 1981). Restriction enzymes were obtained from Northumbria Biologicals, and digests were carried out as recommended by the supplier.

Statistical analysis. All transfer frequencies reported are means of at least two determinations. One-way analysis of variance followed by Tukey's test was used to compare differences between means using the SPSS-X computer package (Hull \& Nie, 1981). All transfer frequencies were transformed by $\log _{10} x$ to ensure normality of distribution and homogeneity of variances. Minimum significant ranges (MSR) were calculated by the TukeyHSD method (Sokal \& Rohlf, 1981). All significant differences are quoted for $P<0.05$.

\section{RESULTS AND DISCUSSION}

\section{Isolation and characteristics of conjugative plasmids in pure cultures}

The mean $( \pm 95 \%$ confidence limits) density of recoverable viable bacteria in the epilithon was $8.8 \pm 6.7 \times 10^{6}$ c.f.u. $\mathrm{cm}^{-2}(n=22)$ and the mean proportion of bacteria resistant to mercury was $2.5 \pm 0.7 \%(n=15)$. Plasmids were more common in the mercury-resistant epilithic bacteria: the frequencies were $47 \%(n=129)$ in unselected bacteria and $70 \%(n=79)$ in mercury-resistant isolates.

The smallest conjugative plasmid reported so far is $28 \mathrm{~kb}$ (pULG14; Thiry, 1984), so only plasmids of $30 \mathrm{~kb}$ or larger were considered to be potentially conjugative in this study. Fortyfour mercury-resistant isolates containing at least one plasmid $\geqslant 30 \mathrm{~kb}$ were used as donors in membrane-filter matings with $P$. aeruginosa PAO2002, PU21, and PAO348 as recipients. None of these isolates transferred mercury resistance (lowest detectable frequency $=1.0 \times 10^{-9}$ ). The isolates included Pseudomonas spp., Alcaligenes spp., Acinetobacter spp., Klebsiella spp., and Citrobacter spp., all of which have been isolated previously from aquatic sources (Nuttall, 1982; Jones et al., 1986).

The proportion of pseudomonad-like mercury-resistant isolates in the epilithon was $7.2 \times 10^{-5} \%$ of the total viable count, and $66 \%(n=32)$ of these contained at least one plasmid $\geqslant 30 \mathrm{~kb}$. Five of these isolates transferred mercury resistance to PAO348 with frequencies ranging from $8.4 \times 10^{-8}$ to $2.8 \times 10^{-3}$ (Table 2). Four of these five isolates contained at least one plasmid which was also detected in the mercury-resistant PAO348 transconjugants. The exception, PAR166, contained a single plasmid, pQM7, which was never detected in the PAO348 transconjugants. The plasmid either integrated into the PAO348 chromosome once it transferred, or was unable to replicate in PAO348 but carried a transposable DNA sequence encoding mercury resistance which inserted into the chromosome. Such transpositional systems have been reported before (Bale et al., 1988) and might be important in natural bacterial populations (Kelly \& Reanney, 1984).

Mercury resistance has been reported to be transferable from $5 \%$ of soil isolates (Kelly \& Reanney, 1984), from $26 \%$ of marine bacteria (Gauthier $e t$ al., 1985), and from $9 \%$ of bacteria isolated from freshwater fish (Toranzo et al., 1984). Our results are similar, as $24 \%$ of the pseudomonad-like isolates transferred mercury resistance to $P$. aeruginosa, although transfer did not occur from random isolates $(<2 \%)$. 
Table 2. Characteristics of epilithic isolates transferring mercury resistance to $P$. aeruginosa PAO348

Donor and recipient organisms were mixed and deposited onto membrane filters. The filters were incubated on PCA for $24 \mathrm{~h}$ at $20^{\circ} \mathrm{C}$; selective plates for donors, recipients and transconjugants were incubated at $20^{\circ} \mathrm{C}$ for $4 \mathrm{~d}$. The presence of plasmids in the transconjugants was confirmed by gel electrophoresis. Isolates were identified using API20B kits and a probabilistic identification matrix (Holmes et al., 1986). Further details are given in Methods.

Epilithic isolate

\begin{tabular}{|c|c|}
\hline $\begin{array}{l}P \text {. putida } \\
P . \text { cepacia }\end{array}$ & $\begin{array}{l}\text { PAR153 } \\
\text { PAR161 }\end{array}$ \\
\hline P. cepacia & PAR 167 \\
\hline $\begin{array}{l}\text { Gram - ve rod } \\
\text { Alteromonas sp. }\end{array}$ & $\begin{array}{l}\text { PAR166: } \\
\text { PAR174 }\end{array}$ \\
\hline
\end{tabular}

Plasmid content of epilithic isolate*

$$
\begin{aligned}
& \text { pQM6, } 190 \mathrm{~kb} ; \mathrm{Tra}^{+}, \mathrm{Hg} \\
& \text { pQM2, } 110 \mathrm{~kb} \\
& \text { pQM3, } 78 \mathrm{~kb} \text {; } \mathrm{Tra}^{+}, \mathrm{Hg}, \text { FMA, merbromin, Sm } \\
& \text { pQM9, } 110 \mathrm{~kb} \\
& \text { pQM8, } 78 \mathrm{~kb} \text {; } \mathrm{Tra}^{+}, \mathrm{Hg}, \text { FMA, merbromin, } \mathrm{Sm} \\
& \text { pQM7, } 90 \mathrm{~kb}\left(\mathrm{Tra}^{+}, \mathrm{Hg}\right) \\
& \text { pQM4, } 172 \mathrm{~kb} ; \mathrm{Tra}^{+}, \mathrm{Hg}, \text { FMA, merbromin } \\
& \text { pQM5, 2.5 kb }
\end{aligned}
$$

Transfer frequency to PAO348†

$$
\begin{aligned}
1.0 & \times 10^{-7} \\
& \mathrm{ND} \\
2.8 & \times 10^{-3} \\
& \mathrm{ND} \\
2.6 & \times 10^{-4} \\
8.4 & \times 10^{-8} \\
2.0 & \times 10^{-5} \\
& \mathrm{ND}
\end{aligned}
$$

\begin{tabular}{|c|c|c|c|}
\hline \multirow{2}{*}{\multicolumn{2}{|c|}{ Recipient bacterium }} & \multicolumn{2}{|c|}{ Transfer frequency } \\
\hline & & pQM3 & pQM4 \\
\hline$P$. aeruginosa & $\begin{array}{l}\text { PAO348 } \\
\text { PU21 }\end{array}$ & $\begin{array}{l}2.8 \times 10^{-3} \\
2.2 \times 10^{-8}\end{array}$ & $\begin{aligned} 2.0 & \times 10^{-5} \\
<4.1 & \times 10^{-10 *}\end{aligned}$ \\
\hline P. putida & KT2440 & $1.9 \times 10^{-2}$ & $2.8 \times 10^{-4}$ \\
\hline & PP3 & $3.9 \times 10^{-7}$ & ND \\
\hline P. fluorescens & AR17 & $5.9 \times 10^{-1}$ & ND \\
\hline & AR41 & $5.3 \times 10^{-6}$ & $<1.4 \times 10^{-7 *}$ \\
\hline & 10038 & $1.4 \times 10^{-8}$ & $<1.5 \times 10^{-9 *}$ \\
\hline P. maltophilia & AR27 & $<1.0 \times 10^{-9 *}$ & $5.0 \times 10^{-9}$ \\
\hline & 10499 & $<1 \cdot 1 \times 10^{-9 *}$ & $1.6 \times 10^{-8}$ \\
\hline A. putrefaciens & 10695 & ND & $3.2 \times 10^{-7}$ \\
\hline E. coli & LE392 & $9.6 \times 10^{-7}$ & $5.2 \times 10^{-3}$ \\
\hline & J53 & $1.7 \times 10^{-6}$ & $4.6 \times 10^{-6}$ \\
\hline A. calcoaceticus & BD413 & $<1.7 \times 10^{-9 *}$ & $<2.0 \times 10^{-9 *}$ \\
\hline Proteus vulgaris & 6213 & $<5.7 \times 10^{-9 *}$ & $<1.5 \times 10^{-8 *}$ \\
\hline K. pneumoniae & 8172 & $<8.5 \times 10^{-9 *}$ & $<7.2 \times 10^{-8 *}$ \\
\hline
\end{tabular}

ND, Transfer of these plasmids was not detected.

* FMA, fluorescein mercuric acetate; Sm, streptomycin.

† Mean of at least three determinations.

$\ddagger$ Although this strain consistently transferred mercury resistance to PAO348, pQM7 was never detected in the transconjugants.

\title{
Table 3. Host ranges of $p Q M 3$ and $p Q M 4$
}

\begin{abstract}
Donor and recipient organisms were mixed and deposited onto membrane filters. The filters were incubated on PCA for $24 \mathrm{~h}$ at $20^{\circ} \mathrm{C}$; selective plates for donors, recipients and transconjugants were incubated at $30^{\circ} \mathrm{C}$ for $48 \mathrm{~h}$. The natural hosts of PQM3 and PQM4, PAR161 and PAR174 respectively, were used as the donors in these matings and rifampicin-resistant mutants of each of the test hosts were used as recipients. Transfer was confirmed by detection of the plasmids in the transconjugants by gel electrophoresis.
\end{abstract}

ND, Not determined.

* Lowest detectable transfer frequency.

Plasmids pQM3 and pQM4 were chosen for further study. Both plasmids encoded resistance to fluorescein mercuric acetate and merbromin but not phenylmercuric acetate or thimerosal (Table 2); thus they encoded narrow-spectrum mercury resistance (Robinson \& Tuovinen, 1984). pQM3 also encoded streptomycin resistance. Both plasmids were broad host range, transferring to a range of Pseudomonas spp. and Escherichia coli but not to Acinetobacter calcoaceticus, Proteus vulgaris or Klebsiella pneumoniae (Table 3). In general, all the mercury- 
resistant transconjugants contained either a single $78 \mathrm{~kb}$ or a single $172 \mathrm{~kb}$ plasmid. However, in $P$. aeruginosa PAO348 and PU21, and $P$. fluorescens AR41, pQM3 underwent structural rearrangements.

The mean ratio of membrane to broth mating transfer frequency was $662(n=4)$ for pQM3 and $>1016(n=2)$ for $\mathrm{pQM} 4$, when the plasmids were transferred from their natural hosts to PAO348. Thus, both plasmids transferred more efficiently on a solid surface than in liquid. This is probably a reflection of the habitat of the natural hosts, on stone surfaces. Not all epilithic plasmids are transferred better on surfaces, however, as pQM1 (Bale et al., 1987) had a plate to broth ratio of 1.9 in these experiments.

\section{Transferable resistances from suspensions of epilithic bacteria}

Mercury, streptomycin and kanamycin resistances were transferred from MNS to the restriction-less $P$. aeruginosa PAO348 with frequencies of $2.2 \times 10^{-5}, 2.2 \times 10^{-6}$ and $7 \cdot 3 \times 10^{-6}$, respectively, but transfer of tellurite or gentamicin resistance was not detected (lowest detectable frequency $=1.0 \times 10^{-8}$ ). Mercury resistance was also transferred to the restriction-less $P$. putida KT2440 $\left(5 \cdot 1 \times 10^{-4}\right)$ but not to the restriction-positive $P$. aeruginosa PU21 $\left(<6.8 \times 10^{-10}\right)$.

\section{Effects of temperature on plasmid transfer}

The epilithic plasmids pQM1 and pQM3 had maximum transfer frequencies at $20-25^{\circ} \mathrm{C}$ (Fig. 1), which was similar to the optimum temperatures reported for two mercury-resistance plasmids isolated from soil $\left(25^{\circ} \mathrm{C}\right.$; Kelly \& Reanney, 1984) and for transfer of antibiotic resistance from a sewage isolate $\left(20-25^{\circ} \mathrm{C}\right.$; Altherr \& Kasweck, 1982). Maximum frequencies for transfer of mercury resistance from a marine pseudomonad to $E$. coli occurred at $30^{\circ} \mathrm{C}$ (Gauthier et al., 1985). These reports suggest that conjugation will be more likely at temperatures higher than those normally expected in temperate aquatic environments. However, our results show that natural plasmids will transfer at environmentally relevant temperatures, because all those studied transferred at $4-6{ }^{\circ} \mathrm{C}$. Transfer of pQM4 occurred maximally at $10-20^{\circ} \mathrm{C}\left(2.5 \times 10^{-5}\right)$ and transfer was not detected above $30^{\circ} \mathrm{C}$ (lowest detectable frequency $\left.=1.0 \times 10^{-9}\right)$. pQM1 transfers in situ at $6^{\circ} \mathrm{C}$ (Bale et al., 1987) but with frequencies 500-fold lower than was demonstrated at the same temperature in these laboratory matings. At $25^{\circ} \mathrm{C}$, pQM3 transferred to $P$. aeruginosa PAO348 with a frequency of $5.8 \times 10^{-3}$. When the natural epilithic isolate $P$. fluorescens AR17 was the recipient, the frequency was much higher $\left(5.9 \times 10^{-1}\right)$ but the temperature optimum remained the same (Fig. 1). Transfer frequencies of RP1 increased as temperature increased, with an optimum at $37-41^{\circ} \mathrm{C}$; hence our results were similar to those obtained previously for R1drd19 and RP1 (Singleton \& Anson, 1981 ; Kelly \& Reanney, 1984).

The transfer of mercury resistance from MNS to PAO348 was studied over a range of physicochemical conditions. Transfer was dependent on temperature (Fig. 2a), with maximum frequencies $\left(2.2 \times 10^{-5}\right)$ occurring at $25^{\circ} \mathrm{C}$. Transfer occurred over the range $8-37^{\circ} \mathrm{C}$ but not at $4{ }^{\circ} \mathrm{C}$ or $41^{\circ} \mathrm{C}$ (lowest detectable frequency $=1.0 \times 10^{-8}$ ). The pattern of temperature sensitivity of transfer of mercury resistance from MNS was similar to that shown from pure cultures. In contrast to our pure culture matings and those of others (George et al., 1981; Walter \& Vennes, 1985), no transfer from natural mixtures of bacteria was detected at below $5^{\circ} \mathrm{C}$ (Fig. $2 a$ ). This failure to detect transfer was probably a reflection of the relatively low densities of potential donors. Since temperature affects bacterial growth rates, $24 \mathrm{~h}$ mating at $4{ }^{\circ} \mathrm{C}$ was probably insufficient time to allow the donor bacteria to reach a high enough density for transfer.

The incubation temperature of the pure cultures of donors and recipients prior to mating was also important in determining the rates of plasmid transfer (Table 4). The transfer frequency of pQM3 was lowest $\left(1.8 \times 10^{-6}\right)$ when the donor $\left(P\right.$. cepacia PAR 161) was grown at $30^{\circ} \mathrm{C}$ prior to mating, and the recipient ( $P$. aeruginosa PAO348) and mating filter were both incubated at $20^{\circ} \mathrm{C}$. Growing PAO348 at $30^{\circ} \mathrm{C}$ gave significantly higher transfer frequencies regardless of the temperature used for growth of PAR161 or for incubation of the mating. Thus, highest 


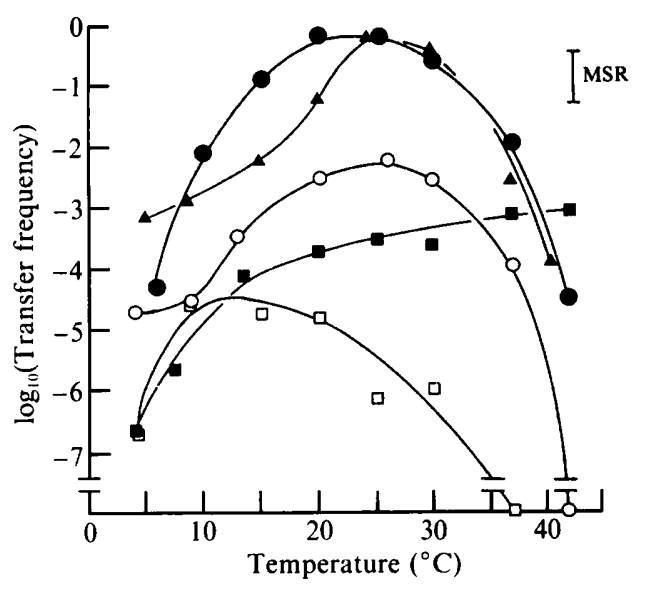

Fig. 1. Effect of temperature on plasmid transfer by conjugation. Plasmids pQM1 (O) and RP1 ( $\square$ ) were transferred from $P$. aeruginosa PAO2002 to $P$. aeruginosa PU21, pQM3 was transferred from $P$. cepacia PAR161 to $P$. aeruginosa PAO348 (O) and $P$. fluorescens AR17 (A), and pQM4 ( $\square$ ) was transferred from Alteromonas sp. PAR 174 to P. aeruginosa PAO348. MSR, minimum significant range.

Table 4. Effect of the incubation temperature of donor and recipient cultures on the transfer of $p Q M 3$

Cultures of donor ( $P$. cepacia PAR161) and recipient ( $P$. aeruginosa PAO348) were grown in NB at $20^{\circ} \mathrm{C}$ or $30^{\circ} \mathrm{C}$, and after filtering the mating mixtures were incubated at $20^{\circ} \mathrm{C}$ or $30^{\circ} \mathrm{C}$. Selective plates for donors, recipients and transconjugants were incubated at the same temperature as that used for the mating.

\section{Temp. for growth of recipients}

$\left({ }^{\circ} \mathrm{C}\right)$

20

30

$$
\begin{aligned}
& \text { Temp. for } \\
& \text { mating }
\end{aligned}
$$

$\left({ }^{\circ} \mathrm{C}\right)$

$$
20
$$$$
30
$$$$
20
$$

30

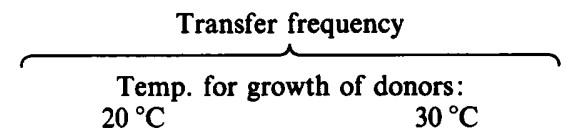

$$
\begin{aligned}
& 3.2 \times 10^{-5} \dagger \\
& 3.5 \times 10^{-5} \dagger \\
& 3.5 \times 10^{-4} \ddagger \S \\
& 9.1 \times 10^{-4} \ddagger
\end{aligned}
$$

$$
\begin{aligned}
& 1.8 \times 10^{-6 *} \\
& 4.8 \times 10^{-5} \dagger \S \\
& 4.8 \times 10^{-4} \ddagger \\
& 7.2 \times 10^{-4} \ddagger
\end{aligned}
$$

* Significantly lower than all other frequencies.

$\dagger, \ddagger$, , Figures with the same symbol were not significantly different.

frequencies were obtained when conditions were optimized for growth of the recipient, indicating that the physiology of bacteria prior to conjugation is important in determining the rates of plasmid transfer.

\section{Effect of $\mathrm{pH}$ on plasmid transfer}

The influence of $\mathrm{pH}$ was investigated at $25^{\circ} \mathrm{C}$ (or $22^{\circ} \mathrm{C}$ ) and $37^{\circ} \mathrm{C}$ because it has been reported that the effects of non-optimal $\mathrm{pH}$ and temperature on plasmid transfer are synergistic (Singleton \& Anson, 1983). A similar synergism was also shown by our results with pure cultures (Fig. $3 a$ ) but not with MNS (Fig. $2 b$ ). There was no effect on the transfer of pQM1 over the range $\mathrm{pH} \mathrm{5.0-8.0} \mathrm{at} 25^{\circ} \mathrm{C}$ but there was a clear optimum at $\mathrm{pH} 6.5$ at $37^{\circ} \mathrm{C}$. At optimum temperature, $\mathrm{pH}$ affected $\mathrm{pQM} 3$ and $\mathrm{RP} 1$ transfer in similar ways, both plasmids having an optimum at $\mathrm{pH} 7 \cdot 0$. The effect of $\mathrm{pH}$ on $\mathrm{pQM} 3$ at $37^{\circ} \mathrm{C}$ was more marked but the optimum was still the same. Transfer from MNS was not significantly affected by $\mathrm{pH}$ over the range 5.5-8.0 (Fig. $2 b$ ) at either $22^{\circ} \mathrm{C}$ or $37^{\circ} \mathrm{C}$. Frequencies at pH 5.0 were significantly lower than those above $\mathrm{pH} 6.5$ at $22^{\circ} \mathrm{C}$ and significantly lower than those at $\mathrm{pH} 7.5$ at $37^{\circ} \mathrm{C}$. Previous studies have shown plasmids to have $\mathrm{pH}$ optima for transfer ranging from 6.0 to 7.5 (Shenderov, 1971 ; 
(a)

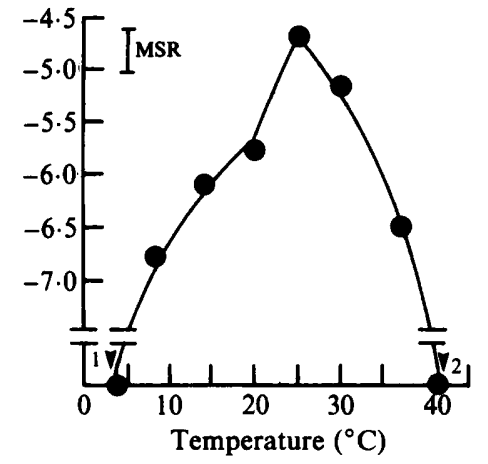

(c)

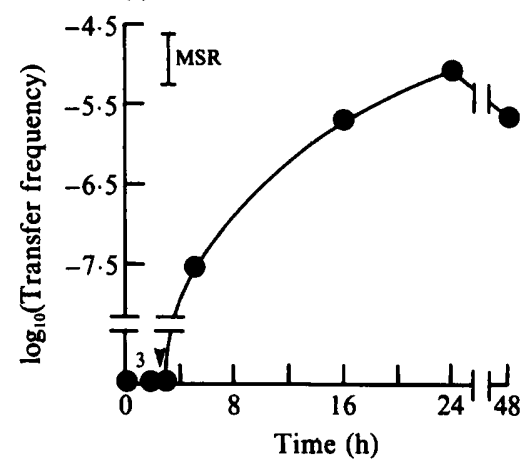

(e)

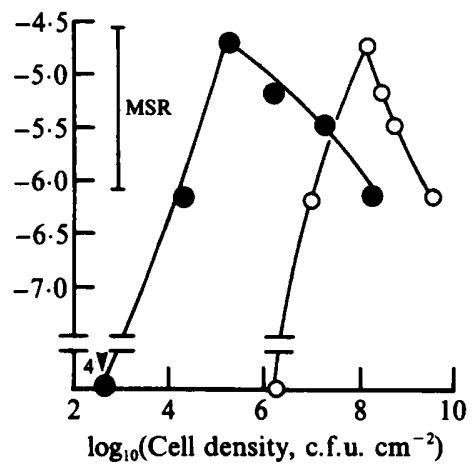

(b)

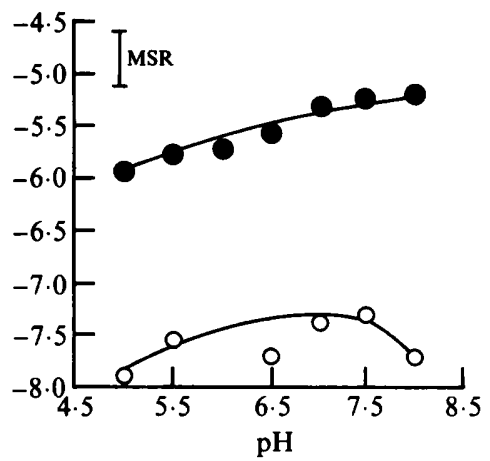

(d)

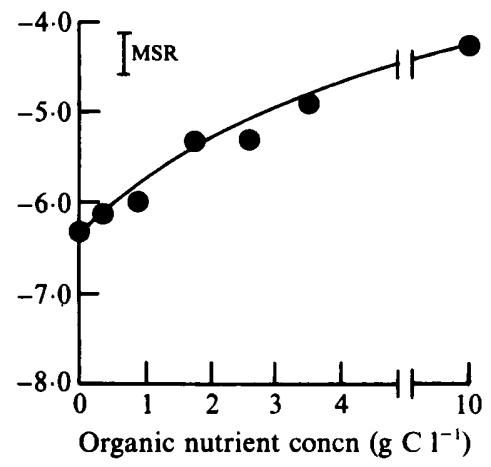

$(f)$

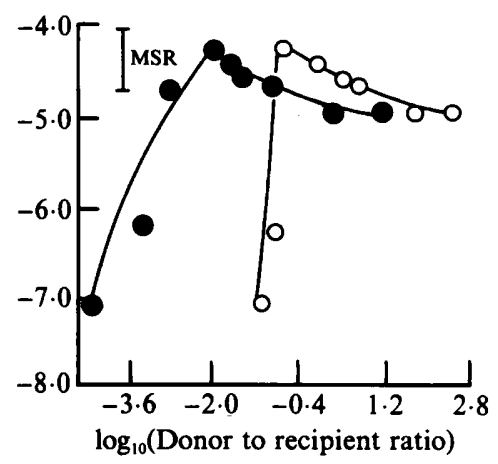

Fig. 2. Factors affecting the conjugal transfer of mercury-resistance plasmids from MNS to $P$. aeruginosa PAO348 on the surface of agar plates. The parameters investigated were: $(a)$ temperature; $(b) \mathrm{pH}$ at $22^{\circ} \mathrm{C}(0)$ and $37^{\circ} \mathrm{C}(O)$; (c) mating time; (d) concentration of organic nutrients; $(e)$ cell density (donors + recipients) at the start $(O)$ and end $(O)$ of the mating period; $(f)$ donor to recipient ratio at the start $(O)$ and end $(O)$ of the mating period. $(\nabla)$ In some individual matings no transfer was detected; the lowest detectable frequencies were (1) $1.4 \times 10^{-8}$, (2) $2.0 \times 10^{-9}$, (3) $5.0 \times 10^{-9}$, (4) $9.2 \times 10^{-9}$. MSR, minimum significant range.

Harada \& Mitsuhashi, 1977; Singleton \& Anson, 1983). The pH of the R. Taff epilithon ranged from 6.2 to 7.0 (measured with a surface $\mathrm{pH}$ meter) over a 12 month period. Since pH values ranging from 5.5 to 8.0 had no effect on plasmid transfer at $22^{\circ} \mathrm{C}$ (Fig. $2 b$ ) it is unlikely that pH would be an important influence on plasmid transfer within the epilithon. 
(a)

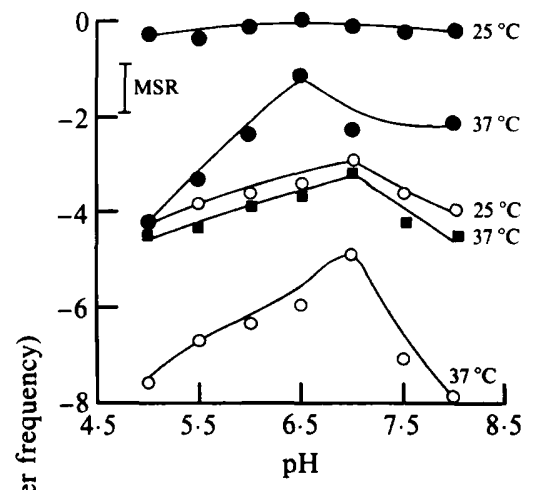

(c)

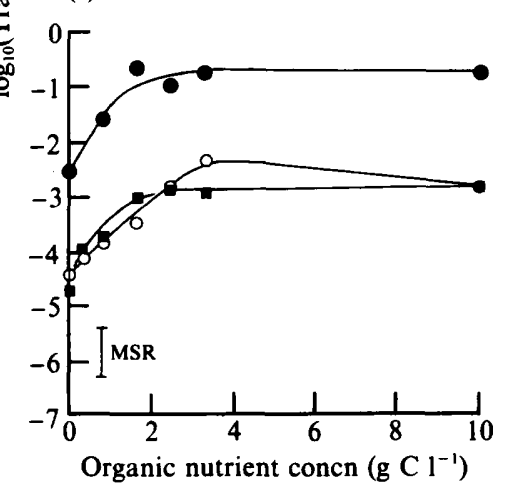

(b)

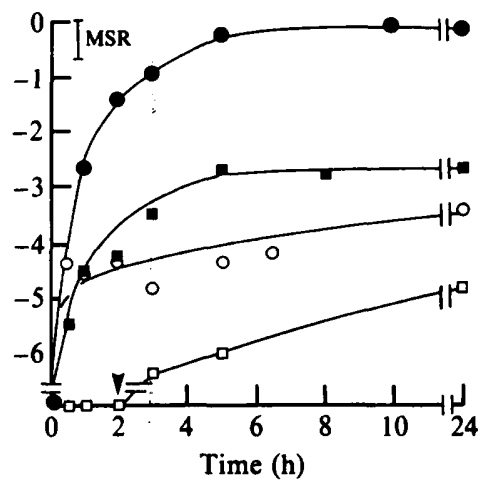

(d)

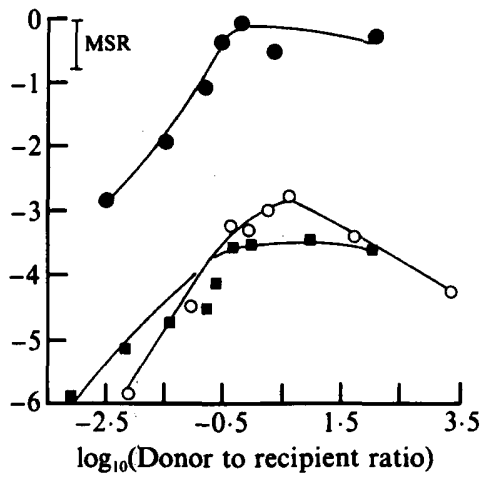

Fig. 3. Effect on conjugal plasmid transfer of $(a) \mathrm{pH}$ at $25^{\circ} \mathrm{C}$ and $37^{\circ} \mathrm{C}$; (b) mating time; (c) nutrient status; and $(d)$ donor to recipient ratio at the start of the mating. Transfer of pQM1 (O) and RPl ( $($ ) was from $P$. aeruginosa PAO2002 to $P$. aeruginosa PU21; pQM3 (O) was transferred from $P$. cepacia PAR161 to $P$. aeruginosa PAO348, and pQM4 $(\square)$ was transferred from Alteromonas sp. PAR174 to $P$. aeruginosa PAO348. $\nabla$, Lowest detectable transfer frequency $=2.0 \times 10^{-8}$. MSR, minimum significant range.

\section{Effect of mating time on plasmid transfer}

Transfer frequencies of RP1 have been reported to reach a maximum after $1 \mathrm{~h}$ (Lacy \& Leary, 1975 ) and $24 \mathrm{~h}$ (Graves \& Riggs, 1980), whereas our results show a maximum frequency after $5 \mathrm{~h}$ (Fig. $3 b$ ). The rate of RP1 transfer thus depends on the host strains and mating conditions used. Both pQM1 and pQM3 also had maximum transfer frequencies after $5 \mathrm{~h}$; increasing the mating time to $24 \mathrm{~h}$ had no significant effect. Transfer of pQM4, however, was not detected within the first $2 \mathrm{~h}$ of mating and the transfer frequency continued to increase beyond $5 \mathrm{~h}$ (Fig. $3 \mathrm{~b}$ ). Increasing the mating period to $48 \mathrm{~h}$ had no significant effect on the transfer of any of the plasmids (results not shown). Transfer from MNS occurred more slowly than from pure cultures, as within the first $3 \mathrm{~h}$ of mating there were no transconjugants (Fig. $2 c ;<1.0 \times 10^{-8}$ ), but low levels were detected after $5 \mathrm{~h}\left(3.2 \times 10^{-8}\right)$ and maximum frequencies were obtained after $24 \mathrm{~h}$. There was a significant decrease in the transfer frequency between $24 \mathrm{~h}$ and $48 \mathrm{~h}$. The donor to recipient ratio after $3 \mathrm{~h}$ mating was $1.9 \times 10^{-4}$ compared to $2.1 \times 10^{-2}$ after $24 \mathrm{~h}$, suggesting that $3 \mathrm{~h}$ mating at $20^{\circ} \mathrm{C}$ was not sufficient time for the epilithic donor population to reach a density at which mating aggregates could form. Thus, the combination of temperature and mating time with donor to recipient ratio appears to be important in determining the efficiency of transfer. A similar interaction between mating time and temperature was reported for transfer of tetracycline resistance from bacteria in raw sewage (Fontaine \& Hoadley, 1976), 
transconjugants being detected after $1 \mathrm{~h}$ at $30^{\circ} \mathrm{C}$ but not until $3.5 \mathrm{~h}$ at $22^{\circ} \mathrm{C}$. Mating time for bacteria within a stable epilithic community should not be a limiting factor on conjugation.

\section{Effect of nutrient concentration on plasmid transfer}

Plasmid transfer frequencies were also dependent on the concentration of nutrients in the mating medium. All of the three plasmids tested transferred on agar with no added carbon (Fig. $3 c$; pQM1, $2.7 \times 10^{-3} ; \mathrm{pQM} 3,3.4 \times 10^{-5} ; \mathrm{RP} 1,2.1 \times 10^{-5}$ ). The transfer frequencies increased with increasing nutrient concentration, up to $1.8 \mathrm{~g} \mathrm{Cl}^{-1}$ for $\mathrm{pQM} 1$ and RP1 and up to $3.5 \mathrm{~g} \mathrm{C}^{-1}$ for pQM3. Increasing the nutrient concentration to $10 \mathrm{~g} \mathrm{C}^{-1}$ had no significant effect on transfer frequencies in these pure-culture matings. The results for MNS were similar. Transfer from MNS occurred on agar plates with no added carbon $\left(4.8 \times 10^{-7}\right)$ and frequencies increased with increasing carbon concentration up to $10 \mathrm{~g} \mathrm{C}^{-1}\left(5 \cdot 7 \times 10^{-5} ;\right.$ Fig. $\left.2 d\right)$. Other reports support these findings. For example, the transfer of RP4 between Rhizobium strains increased with increasing carbon concentration (Beringer, 1974). The increase of transfer frequencies with nutrient concentration indicates that the physiology of bacteria involved in conjugation is an important determinant. Growth rates of bacteria also increase with increasing nutrient concentration and it has been shown that in $E$. coli there is a positive correlation between multiplication rates of donor and recipient bacteria and fertility (Levin et al., 1979). Plasmid transfer in sterile stream water occurred only when it was amended with dilute nutrient broth (Trevors \& Oddie, 1986). Mobilization of pHSV106 in a waste treatment model, however, was not affected by nutrient composition or concentration (Mancini et al., 1987).

\section{Effect of the ratio of donors and recipients on plasmid transfer}

It has been reported previously that plasmid transfer frequency is affected by the ratio of donors and recipients in the mating. Gauthier et al. (1985) reported that the majority of plasmids from mercury-resistant marine isolates transferred maximally at donor to recipient ratios of 1 , and Graves \& Riggs (1980) reported that RP1 transfer frequencies were higher at initial ratios $\geqslant 15$ than at ratios $\leqslant 1$. Our results show maximum transfer frequencies of $p Q M 1, p Q M 3$, and RP1 at initial donor to recipient ratios of 0.4-30, depending on the plasmid, but all three plasmids transferred over the range of ratios used (Fig. $3 d$ ). The transfer of mercury resistance from MNS occurred over a wide range of initial donor to recipient ratios (Fig. $2 f$ ) but maximum frequencies were at ratios greater than $1.6 \times 10^{-2}$. The donor to recipient ratios changed over the course of the matings because of differential growth rates of donors and recipients, but transfer frequencies plotted against ratios at the end of the mating showed the same trends, in both MNS matings (Fig. $2 f$ ) and pure-culture matings (not shown).

\section{Effect of cell density on plasmid transfer}

The influence of cell density on plasmid transfer was studied for MNS matings only (Fig. 2e). Transfer frequencies were plotted against the cell densities at the start and the end of the $24 \mathrm{~h}$ mating period. Maximum frequencies $\left(2.0 \times 10^{-5}\right)$ were obtained when the matings contained an initial density (donors + recipients) of $1.7 \times 10^{5}$ c.f.u. $\mathrm{cm}^{-2}$. After $24 \mathrm{~h}$ the cell density in this mating had increased to $1.4 \times 10^{8}$ c.f.u. $\mathrm{cm}^{-2}$. The lowest initial density at which transfer was detected was $2.2 \times 10^{4}$ c.f.u. $\mathrm{cm}^{-2}$ (frequency $=6.6 \times 10^{-7}$ ), which increased to a density of $9.7 \times 10^{6}$ c.f.u. $\mathrm{cm}^{-2}$ after $24 \mathrm{~h}$ mating. No transfer was detected when the initial density was $4.4 \times 10^{2}$ c.f.u. $\mathrm{cm}^{-2}$, even though the density in this mating had increased to $1.9 \times 10^{6}$ c.f.u. $\mathrm{cm}^{-2}$ after $24 \mathrm{~h}$. We conclude that $24 \mathrm{~h}$ mating did not allow the initial population of $4.4 \times 10^{2}$ c.f.u. $\mathrm{cm}^{-2}$ to increase sufficiently for mating aggregates to form. The absence of transfer below a critical cell density, as observed here, has also been reported for previous plasmid transfer studies (Gowland \& Slater, 1984; Manceau et al., 1986).

\section{Effect of anaerobiosis on plasmid transfer between pure cultures}

Both aerobic and anaerobic zones occur within the epilithon (Lock et al., 1984), so we tested the ability of epilithic plasmids to transfer in anaerobic matings. When donor and recipient pregrowth, mating and selection were performed anaerobically, RP1 showed no significant 
Table 5. Effects of anaerobiosis on plasmid transfer

\begin{abstract}
Donor and recipient organisms were deposited onto membrane filters. RP1 and pQM1 were transferred from $P$. aeruginosa PAO2002 to $P$. aeruginosa PU21 and pQM3 was transferred from $P$. cepacia PAR161 to $P$. aeruginosa PAO348. Anaerobic matings were performed on PCA $+0.5 \% \mathrm{KNO}_{3}$ for $24 \mathrm{~h}$ at $25^{\circ} \mathrm{C}$ in an anaerobic cabinet with: (a) anaerobic conditions used for donor and recipient pregrowth and selection subsequent to mating, $(b)$ pregrowth under anaerobiosis but selective plates incubated aerobically, $(c)$ donor and recipient cultures and selective plates incubated aerobically. Standard aerobic matings and aerobic matings on PCA $+0.5 \% \mathrm{KNO}_{3}$ were also carried out.
\end{abstract}

$\begin{array}{lcccc}\text { Mating conditions } & \overbrace{\mathrm{RP1}} & \mathrm{pQM1} & \mathrm{pQM3} \\ \text { Aerobic } & & 2.0 \times 10^{-4 *} & 4.0 \times 10^{-1 *} & 3.4 \times 10^{-3 *} \\ \text { Aerobic }+5 \% \mathrm{KNO}_{3} & 2.3 \times 10^{-4 *} & 6.2 \times 10^{-1 *} & 7.3 \times 10^{-3 *} \\ \text { Anaerobic }+5 \% \mathrm{KNO}_{3} & (\text { a }) & 5.8 \times 10^{-4 *} & 0 \dagger & 0 \dagger \\ & (\text { b }) & \mathrm{ND} & 0 \dagger & 6.7 \times 10^{-3 *} \\ & (\text { c }) & 1.4 \times 10^{-5} & 0 \dagger & 1.3 \times 10^{-4}\end{array}$

ND, Not determined.

* Not significantly different (for each plasmid).

$\dagger$ Lowest detectable frequency was $10^{-9}$.

$\ddagger$ Lowest detectable frequency was $10^{-7}$.

change in its transfer frequency (Table 5). This contrasts with a previous report (Graves \& Riggs, 1980) that RP1 transfer frequencies from $P$. aeruginosa to $E$. coli were 400 -fold lower in anaerobic matings compared to aerobic. Under such wholly anaerobic conditions, transfer of pQM1 and pQM3 was not detected. However, pQM3 could transfer anaerobically because when pregrowth and mating were carried out anaerobically, but selective plates were incubated aerobically (Table 5), transfer was as efficient as in aerobic matings. PAO348 and PAO348(pQM3) were streaked onto $\mathrm{PCA}+0.5 \% \mathrm{KNO}_{3}$ plates without mercury and incubated anaerobically at $30^{\circ} \mathrm{C}$ for $3 \mathrm{~d}$. All PAO348(pQM3) strains $(n=15)$ were unable to grow under these conditions whereas growth of plasmid-free PAO348 was unaffected. Thus, the presence of pQM3 prevented anaerobic growth of PAO348. P. cepacia PAR161 was not able to grow anaerobically although it did remain viable over $24 \mathrm{~h}$, thus demonstrating the ability of pQM3 to transfer under anaerobiosis even though its natural host did not grow under these conditions. Unlike that of $\mathrm{pQM} 3$, transfer of $\mathrm{pQM} 1$ was completely inhibited by anaerobiosis, suggesting an oxygen requirement other than as terminal electron acceptor, as this role was fulfilled by $\mathrm{KNO}_{3}$ in these experiments. Anderson (1975) reported that transfer of R1 was completely inhibited by anaerobiosis; and inhibition of R1 fertility was shown to be dependent on anaerobic conditions during pregrowth of the donor strain (Burman, 1975), with oxygen tension during recipient pregrowth, mating and selection having no effect.

\title{
Overall discussion on factors affecting plasmid transfer
}

These results demonstrated the presence of broad-host-range conjugative plasmids in the epilithon and showed that they are capable of transfer under environmentally relevant conditions. The plasmids from pure cultures of epilithic bacteria, RP1 and plasmids from MNS showed similar transfer behaviour for all of the variables studied except temperature. The RP1 temperature profiles were very different, all the epilithic plasmids showing much poorer transfer at higher temperatures. The epilithic plasmids therefore had optima for transfer at temperatures which prevail in the environment from which they were isolated. Epilithic bacteria are exposed to a maximum temperature of $21^{\circ} \mathrm{C}$ in the $\mathrm{R}$. Taff whereas $\mathrm{RP1}$ was originally isolated from a clinical strain of $P$. aeruginosa (Lowbury et al., 1969). The same hosts were used in the RP1 and pQM1 transfer experiments (Fig. 1), which demonstrates that both the bacterial hosts (Table 3; Bale et al., 1987) and the plasmid itself have roles in determining transfer.

Several of our experiments also show that the host physiology affects plasmid transfer. So, it is probable that factors affecting plasmid transfer in the environment will include the physico- 


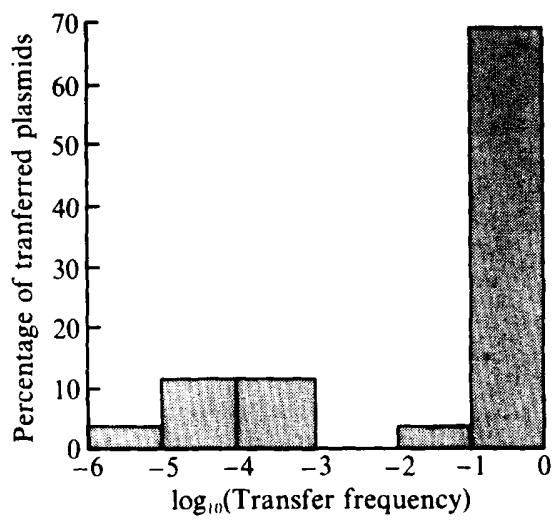

Fig. 4. Distribution of transfer frequencies of MNS plasmids when transferred from their original transconjugants, $P$. aeruginosa PAO348, to $P$. putida KT2440 in membrane filter matings at $25^{\circ} \mathrm{C}$.

Table 6. Characteristics of the predominant type of plasmid transferred from MNS

Plasmids were transferred from MNS to $P$. aeruginosa PAO348 in matings on the surface of PCA plates at $20^{\circ} \mathrm{C}$ for $24 \mathrm{~h}$. The plasmids were then transferred from these transconjugants into $P$. putida KT2440 in membrane filter matings. Recipients and transconjugants were selected on minimal salts agar + glucose $\left(1 \mathrm{~g} \mathrm{l}^{-1}\right) \pm \mathrm{HgCl}_{2}\left(13.5 \mu \mathrm{g} \mathrm{ml}^{-1}\right)$. Plasmids were prepared by sucrose gradient centrifugation (Wheatcroft \& Williams, 1981) and analysed by EcoRI restriction digests. The sizes were calculated by summing the fragment sizes determined by multiple regression (Rochelle et al., 1986).

$\begin{array}{ll}\begin{array}{c}\text { Plasmid and } \\ \text { phenotype }\end{array} & \begin{array}{c}\text { Siz } \\ (\mathrm{kb})\end{array} \\ \text { pQM120 } \mathrm{Tra}^{+} \mathrm{Hg} \mathrm{Uv} & 316 \\ \text { pQM122 } \mathrm{Tra}^{+} \mathrm{Hg} \mathrm{Uv} & 331 \\ \text { pQM124 } \mathrm{Tra}^{+} \mathrm{Hg} \mathrm{Uv} & 334 \\ \text { pQM127 } \mathrm{Tra}^{+} \mathrm{Hg} \mathrm{Uv} & 32 \\ \text { pQM141 } \mathrm{Tra}^{+} \mathrm{Hg} \mathrm{Uv} & 316 \\ \text { pQM181 } \mathrm{Tra}^{+} \mathrm{Hg} \mathrm{Uv} \mathrm{Sm} & 327\end{array}$

\section{Size} (kb)

316

$$
331
$$

* Number of plasmids with identical restriction patterns.

$\dagger$ Transferred from $P$. aeruginosa PAO348 to $P$. putida KT2440.
Transfer frequency $\dagger$

$7.9 \times 10^{-1}$ $5.6 \times 10^{-1}$ $6.2 \times 10^{-1}$ $4.8 \times 10^{-1}$ $1.4 \times 10^{-4}$ $1.1 \times 10^{-6}$

chemical conditions, the host physiology and the types of plasmid present. The synergism between the effects of $\mathrm{pH}$ and temperature on transfer suggests that combinations of other variables will also have complex effects. For example, temperature affects growth rate and nutritional requirements of bacteria (Herbert \& Bhakoo, 1979), so an interaction between temperature and nutrient status, which also affects growth rate, would be expected. Therefore, rates of transfer will not be determined by a single factor but by a complex interaction of many variables. Thus, accurate predictions of gene transfer in natural environments will be difficult.

\section{Characteristics of plasmids from MNS}

Mercury-resistant $P$. aeruginosa PAO348 transconjugants from an MNS mating at $20^{\circ} \mathrm{C}$,

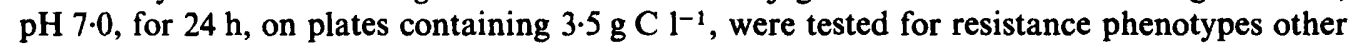
than mercury. The only resistance detected was for streptomycin and this was found in only two of the 100 transconjugants tested. All but two of the transconjugants contained single plasmids, the majority $(80 \%)$ of which were larger than $300 \mathrm{~kb}$. PAO348 did not give reliable or consistent plasmid yields from density gradient centrifugation (Wheatcroft \& Williams, 1981), therefore the plasmids were transferred into $P$. putida KT2440, using membrane matings, and from there analysed by restriction digests. Forty-eight of the PAO348 transconjugants (54\%) transferred their plasmids to KT2440 with frequencies ranging from $1.1 \times 10^{-6}$ to $8.2 \times 10^{-1}$ (Fig. 4). 


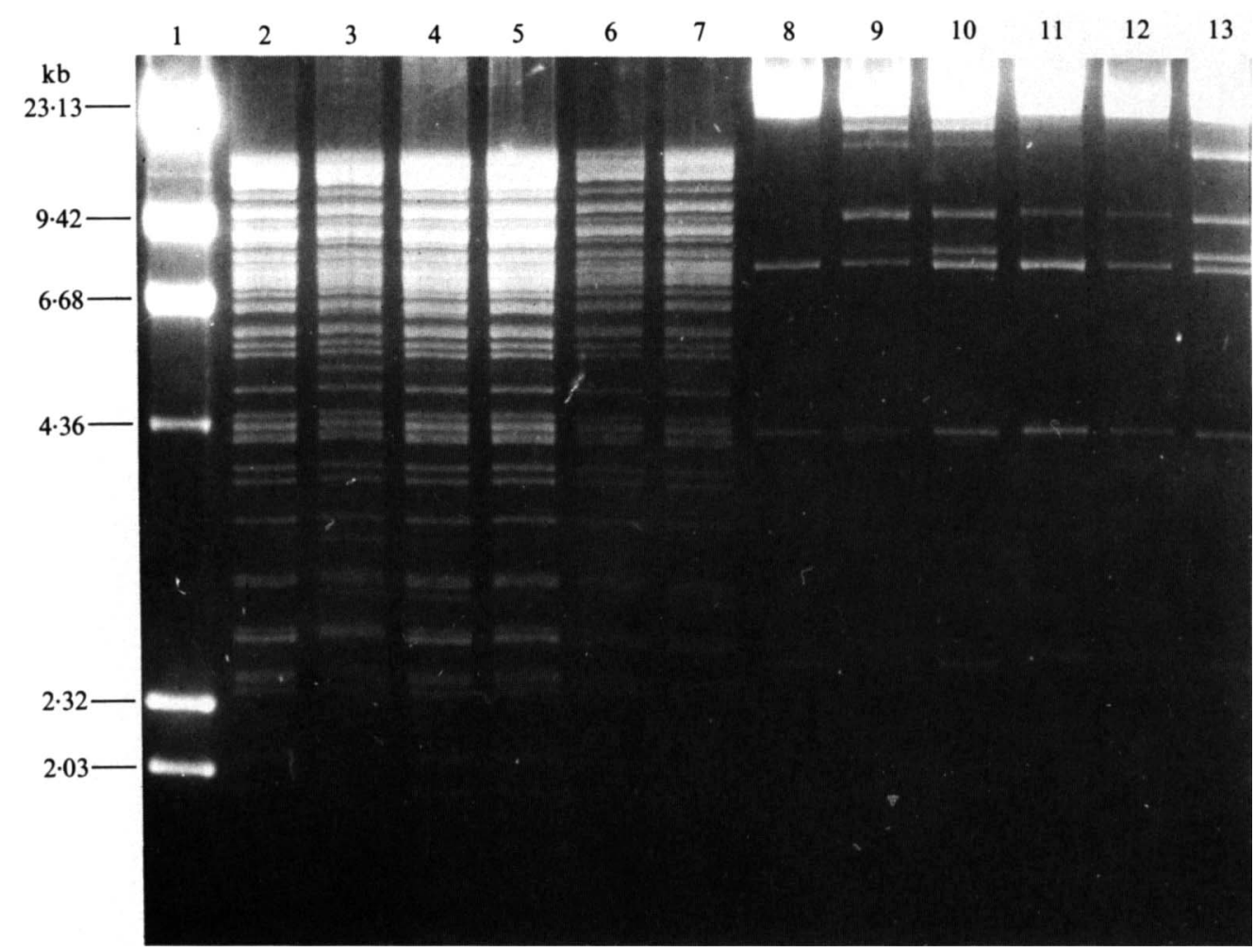

Fig. 5. Restriction digests of MNS plasmids transferred from $P$. aeruginosa PAO348 to $P$. putida KT2440. Lanes: (1) HindIII digest of $\lambda$ DNA (fragment sizes are shown on the left), (2) and (8) pQM120, (3) and (9) pQM122, (4) and (10) pQM124, (5) and (11) pQM127, (6) and (12) pQM134, (7) and (13) pQM181. Lanes (2) to (7) were digested with EcoRI and (8) to (13) with Sall.

A random sample of 21 of the plasmids that transferred to KT2440 was examined further. Restriction digests with EcoRI and SalI showed that the majority (16) of the large (>300 kb) plasmids were indistinguishable, producing the same digest patterns. SalI was used because complete digestion with this enzyme gave fewer bands than with EcoRI and HindIII so differences between plasmids showed up more clearly. One of these plasmids (pQM120) was used as a standard for further comparisons (Table 6). This plasmid encoded UV resistance and was found to be about $320 \mathrm{~kb}$ in size by $E c o$ RI and $H$ indIII digests. The remaining five plasmids had alterations of between two and five fragments, accounting for $<5 \%$ of the total plasmid DNA (Figs 5 and 6). Table 6 summarizes the characteristics of the pQM120-type plasmids. With the exception of $\mathrm{pQM} 181$ these plasmid alterations had no effect on the detectable phenotype. In addition to mercury and UV resistance, pQM181 encoded streptomycin resistance, which was probably located on the additional $7.9 \mathrm{~kb}$ fragment (Fig. 6). It transferred from PAO348 to KT2440 with a frequency of $1 \cdot 1 \times 10^{-6}$. The second plasmid from MNS which encoded streptomycin resistance, $\mathrm{pQM} 194$, was $180 \mathrm{~kb}$, sensitive to UV irradiation and did not transfer to $\mathrm{KT} 2440\left(<1.0 \times 10^{-9}\right)$. pQM141 was indistinguishable from pQM120 but transferred from PAO348 to KT2440 at a much lower frequency $\left(1.4 \times 10^{-4}\right)$. The original PAO348 transconjugant contained a second plasmid $(200 \mathrm{~kb})$ which did not transfer to KT2440 but presumably inhibited the fertility of $\mathrm{pQM} 141$.

The cryptic fragments present in the pQM120-type plasmids may be a result of rearrangements occurring either before or after transfer of the plasmids into PAO348. However, the $7.9 \mathrm{~kb}$ fragment encoding streptomycin resistance on $\mathrm{pQM} 181$ was probably a result of a rearrangement which occurred within the epilithon because there were no streptomycin resistance genes expressed in the recipient strains used. Streptomycin resistance was also the 


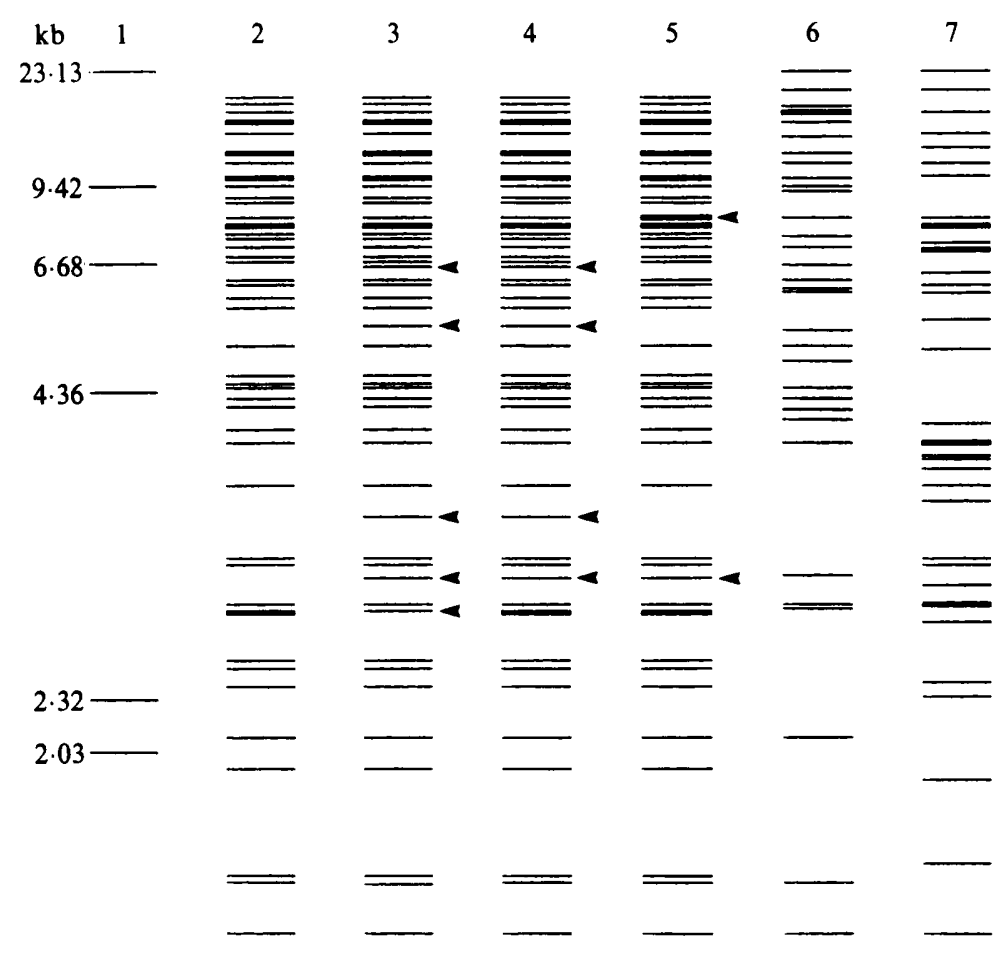

Fig. 6. Diagrammatic representation of EcoRI digests of some plasmids from MNS in $P$. putida KT2440. Lanes: (1) HindIII digest of $\lambda$ DNA (fragment sizes are shown on the left), (2) pQM120, (3) pQM122, (4) pQM124, (5) pQM181, (6) pQM1, (7) pQM40. Arrows indicate the fragments that differ from the most common digest pattern (pQM120). Thick lines represent fragments of identical size which could not be separated by electrophoresis. The diagrams were constructed from a number of electrophoresis gels, run for varying times to clearly separate the fragments.

only phenotype other than mercury resistance which was detected on plasmids isolated from the pure cultures of epilithic bacteria.

The first mercury-resistance plasmid isolated from the R. Taff epilithon was pQM1 (Bale et al., 1987). Comparison of the EcoRI digest patterns of pQM1 and pQM120 (Fig. 6) shows some similarity ( $58 \%$ of the bands). However, the two largest bands of both plasmids were different, and as these accounted for about $30 \%$ of the DNA it is unlikely that pQM1 and pQM120 are structurally similar. Another plasmid from epilithic bacteria in the R. Taff, pQM40 (one of the pQM39 group; M. J. Bale, personal communication), is dissimilar from pQM1 (Bale et al., 1988) and also appeared different from PQM120 on the basis of our EcoRI digests (Fig. 6). All the other 18 large (250-269 kb) plasmids isolated by Bale et al. (1988) gave large numbers of fragments with $S a I$ digestion and so were probably unrelated to the pQM120-like plasmids isolated in this study. UV resistance is probably very common in the epilithon, as $80 \%$ of the plasmids isolated by Bale et al. (1988), and all of those isolated from MNS in the present study conferred this phenotype. Different genera of bacteria from another aquatic habitat (Jobling $e t$ $a l ., 1988)$ have also been found to contain identical and related plasmids.

Our results and other reports (Jobling et al., 1988; Bale et al., 1988) therefore indicate that populations of plasmids encoding mercury resistance within aquatic bacteria have the potential for transfer and structural rearrangements, thus allowing for acquisition and dissemination of phenotypes. The method we describe here for isolating plasmids from MNS could have more general application. It appears to be good at isolating plasmids which transfer at high frequency and so are perhaps actively transferring in nature.

This work was supported by a Natural Environment Research Council grant. 


\section{REFERENCES}

AltherR, M. R. \& KaSWECK, K. L. (1982). In situ studies with membrane diffusion chambers of antibiotic resistance transfer in Escherichia coli. Applied and Environmental Microbiology 44, 838-843.

ANDERSON, J. D. (1975). Factors that may prevent transfer of antibiotic resistance between Gramnegative bacteria in the gut. Journal of Medical Microbiology 8, 83-88.

BACHMANN, B. J. (1987). Derivations and genotypes of some mutant derivatives of $E$. coli K12. In Escherichia coli and Salmonella typhimurium: Cellular and Molecular Biology, pp. 1190-1219. Edited by F. C. Neidhardt, J. L. Ingraham, K. B. Low, B. Magasanik, M. Schaechter \& H. E. Umbarger. Washington, DC: American Society for Microbiology.

Bagdasarian, M., Lurz, R., Ruckert, B., Franklin, F. C. H., Bagdasarian, M. M., Frey, J. \& Timmis, K. N. (1981). Specific-purpose plasmid cloning vectors. II. Broad host range, high copy number, RSF1010-derived vectors, and a host-vector system for gene cloning in Pseudomonas. Gene 16, 237-247.

Bale, M. J., FrY, J. C. \& DAY, M. J. (1987). Plasmid transfer between strains of Pseudomonas aeruginosa on membrane filters attached to river stones. Journal of General Microbiology 133, 3099-3107.

BaLe, M. J., FRY, J. C. \& DAY, M. J. (1988). Transfer and occurrence of large mercury resistance plasmids in river epilithon. Applied and Environmental Microbiology 54, 972-978.

BERINGER, J. E. (1974). R factor transfer in Rhizobium leguminosarum. Journal of General Microbiology 84, 188-198.

Burman, L. G. (1975). Amplification of sex repressor function of one $f^{+} \mathbf{R}$ factor during anaerobic growth of Escherichia coli. Journal of Bacteriology 123, 265271.

Burton, N. F., DAY, M. J. \& Bull, A. T. (1982). Distribution of bacterial plasmids in clean and polluted sites in a South Wales river. Applied and Environmental Microbiology 44, 1026-1029.

Chandler, P. M. \& KRISHNaPILlai, V. (1974). Isolation and properties of recombination-deficient mutants of Pseudomonas aeruginosa. Mutation Research 23, 15-23.

Fontain, T. D. \& Hoadley, A. W. (1976). Transferable drug resistance associated with coliforms isolated from hospital and domestic sewage. Hospital Laboratory Sciences 13, 238-245.

Gauthier, M. J., Cauvin, F. \& Breittmayer, J. P. (1985). Influence of salts and temperature on the transfer of mercury resistance from a marine pseudomonad to Escherichia coli. Applied and Environmental Microbiology 50, 38-40.

George B. A., Fagerberg, D. J. \& Sanem, J. A. (1981). Antimicrobial resistance transfer in transport media. Applied and Environmental Microbiology 42, 548-549.

Glassman, D. L. \& McNicol, L. A. (1981). Plasmid frequency in natural populations of estuarine microorganisms. Plasmid 5, 231.

Gowland, P. C. \& SlateR, J. H. (1984). Transfer and stability of drug resistance plasmids in Escherichia coli strain K12. Microbial Ecology 10, 1-13.
Graves, J. F. \& Riggs, H. G. (1980). Anaerobic transfer of antibiotic resistance from Pseudomonas aeruginosa. Applied and Environmental Microbiology 40, $1-6$.

HADA, H. S. \& SIzEMORE, R. K. (1981). Incidence of plasmids in marine Vibrio spp., isolated from an oil field in the Northwestern Gulf of Mexico. Applied and Environmental Microbiology 41, 199-202.

HARADA, K. \& MitsuHashi, S. (1977). Physiology of R factors. In $R$ Factor Drug Resistance Plasmid, pp. 135-160. Edited by S. Mitsuhashi, Tokyo: University Park Press.

Herbert, R. A. \& Bhakoo, M. (1979). Microbial growth at low temperatures. In Cold Tolerant Microbes in Spoilage and the Environment, pp. 1-16. Edited by A. D. Russell \& R. Fuller. London: Academic Press.

Holmes, B., Pinning, C. A. \& Dawson, C. A. (1986). A probability matrix for the identification of Gramnegative, aerobic, non-fermentative bacteria that grow on nutrient agar. Journal of General Microbiology 132, 1827-1842.

HuLL, C. H. \& NIE, N. H. (1981). SPSS Update: New Procedures and Facilities for Release 7.9. New York: McGraw-Hill.

JACOBY, G. A. (1974). Properties of $R$ plasmids determining gentamicin resistance by acetylation in Pseudomonas aeruginosa. Antimicrobial Agents and Chemotherapy 6, 239-252.

Jobling, M. G., Peters, S. E. \& Ritchie, D. A. (1988). Plasmid-borne mercury resistance in aquatic bacteria. FEMS Microbiology Letters 49, 31-37.

Jones, J. G., GARDENer, S., SIMON, B. M. \& PickUP, R. W. (1986). Antibiotic resistant bacteria in Windermere and two remote upland tarns in the English Lake District. Journal of Applied Bacteriology 60, 443-453.

KADO, C. I. \& LIU, S. T. (1981). Rapid procedure for detection and isolation of large and small plasmids. Journal of Bacteriology 145, 1365-1373.

Kelly, W. J. \& ReanNey, D. C. (1984). Mercury resistance among soil bacteria: ecology and transferability of genes encoding resistance. Soil Biology and Biochemistry 16, 1-8.

Kobori, H., Sullivan, C. W. \& ShizuYa, H. (1984). Bacterial plasmids in antarctic natural microbial assemblages. Applied and Environmental Microbiology 48, 515-518.

LACY, G. H. \& LEARY, J. V. (1975). Transfer of antibiotic resistance factor RPl into Pseudomonas glycinea and Pseudomonas phaseolicola in vitro and in planta. Journal of General Microbiology 88, 49-57.

LeVIN, B. R., Stewart, F. M. \& RICE, V. A. (1979). The kinetics of conjugative plasmid transmission : fit of a simple mass action model. Plasmid 2, 247-260.

Lock, M. A., Wallace, R. P., Costerton, J. W., Ventullo, R. M. \& Charlton, S. E. (1984). River epilithon: toward a structural and functional model. Oikos 42, 10-22.

LowbURY, E. J. L., KIDSON, A., LILly, H. A., AYLIFFe, G. A. \& JONEs, R. J. (1969). Sensitivity of Pseudomonas aeruginosa to antibiotics: emergence of strains highly resistant to carbenicillin. Lancet $i i$, 448-452. 
Manceau, C., Gardan, L. \& DevauX, M. (1986). Dynamics of RP4 plasmid transfer between Xanthomonas campestris pv. corylina and Erwinia herbicola in hazelnut tissues, in planta. Canadian Journal of Microbiology 32, 835-841.

Mancini, P., Fertels, S., Nave, D. \& Gealt, M. A. (1987). Mobilisation of plasmid pHSV106 from Escherichia coli $\mathrm{HB} 101$ in a laboratory scale waste treatment facility. Applied and Environmental Microbiology 53, 665-671.

Maniatis, T., Fritsch, E. F. \& Sambrook, J. (1982). Molecular Cloning: a Laboratory Manual. Cold Spring Harbor, NY: Cold Spring Harbor Laboratory.

Mawle, G. W., Winstone, A. \& Brooker, M. P. (1985). Salmon and sea trout in the Taff - past, present and future. Nature in Wales New Series 4 (102), 36-45.

NUTTALL, D. (1982). The populations, characterisation and activity of suspended bacteria in the Welsh River Dee. Journal of Applied Bacteriology 53, 49-59.

Robinson, J. B. \& Tuovinen, O. H. (1984). Mechanisms of microbial resistance and detoxification of mercury and organomercury compounds: physiological, biochemical, and genetic analyses. Microbiological Reviews 48, 95-124.

RoChelle, P. A., Fry, J. C., DAY, M. J. \& BAle, M. J. (1986). An accurate method for estimating sizes of small and large plasmids and DNA fragments by gel electrophoresis. Journal of General Microbiology 132, 53-59.

Senior, E., Bull, A. T. \& Slater, J. H. (1976). Enzyme evolution in a microbial community growing on the herbicide Dalapon. Nature, London 263, 476-479.

Shaw, D. R. \& Cabelli, V. J. (1980). R plasmid transfer from environmental isolates of Escherichia coli to laboratory and fecal strains. Applied and Environmental Microbiology 40, 756-764.
Shenderov, B. S. (1971). The effect of temperature, $\mathrm{pH}$, and composition of medium on transmission of drug resistance by conjugation. Zhurnal Mikrobiologii, Epidemiologii i Immunobiologii 48, 94-98.

Simon, R. D., Shilo, M. \& Hastings, J. N. (1982). The absence of a correlation between plasmids and luminescence in marine luminous bacteria. Current Microbiology 7, 175-180.

Singleton, P. \& ANSON, A. E. (1981). Conjugal transfer of R-plasmid R1drd 19 in E. coli below $22^{\circ} \mathrm{C}$. Applied and Environmental Microbiology 42, 789-791.

Singleton, P. \& ANSON, A. E. (1983). Effect of pH on conjugal transfer at low temperatures. Applied and Environmental Microbiology 46, 291-292.

SOKAL, R. R. \& ROHLF, F. J. (1981). Biometry, 2nd edn. San Francisco: Freeman.

THIRY, G. (1984). Plasmids of the epiphytic bacterium Erwinia uredovora. Journal of General Microbiology 130, 1623-1631.

Toranzo, A. E., Combarro, P., Lemos, M. L. \& BORJA, J. L. (1984). Plasmid coding for transferable drug resistance in bacteria isolated from cultured Rainbow trout. Applied and Environmental Microbiology 48, 872-877.

Trevors, J. T. \& OdDIE, K. M. (1986). R-plasmid transfer in soil and water. Canadian Journal of Microbiology 32, 610-613.

Van Hartingsveldt, J., Marinus, M. G. \& StouthAMER, A. H. (1971). Mutants of Pseudomonas aeruginosa blocked in nitrate or nitrite dissimilation. Genetics 67, 469-482.

W ALTER, M. V. \& VENNES, J. W. (1985). Occurrence of multiple antibiotic resistant enteric bacteria in domestic sewage and oxidation lagoons. Applied and Environmental Microbiology 50, 930-933.

Wheatcroft, R. \& Williams, P. A. (1981). Rapid method for the study of both stable and unstable plasmids in Pseudomonas. Journal of General Microbiology 124, 433-437. 